\title{
Age Estimation of Sea Scallop Larvae (Placopecten magellanicus) from Daily Growth Lines on Shells
}

\author{
G. V. Hurley \\ Hurley Fisheries Consulting Ltd., 52 King Street \\ Dartmouth, Nova Scotia, Canada B2Y 2 R5 \\ M. J. Tremblay \\ Department of Fisheries and Oceans, Biological Sciences Branch \\ P. O. Box 550, Halifax, Nova Scotia, Canada B3J 257 \\ C. Couturier \\ Department of Biology, Dalhousie University \\ Halifax, Nova Scotia, Canada B3H 4J1
}

\begin{abstract}
Larval sea scallops (Placopecten magellanicus) were reared in the laboratory and their shell growth lines were counted and used to estimate age in days. The first growth line was deposited 3 to 4 days after fertilization. Age estimates from growth-line counts were strongly correlated with the actual ages of the larvae. Photoperiod had no detectable effect on the rate of growth-line deposition.
\end{abstract}

\section{Introduction}

Studies of the larval ecology of sea scallops (Placopecten magellanicus) would be greatly enhanced if it was possible to age the larvae. In comparison with what is now possible, estimates of such parameters as growth and mortality rates, duration of the pelagic phase, and date of spawning of a particular cohort of larvae would be much more reliable. Growth lines, which can be defined as abrupt or repetitive changes in the character of an accreting tissue (Clark, 1974), represent a potentially-useful ageing tool. Such lines have been used extensively for ageing adult molluscs (Clark, 1968; Rhoads and Lutz, 1980; Thompson et al., 1980; Jones, 1983), but there have been few investigations into the application of growth lines for ageing larvae. Millar (1968) reported that the shells of larval oysters appeared to have daily lines which were deposited under constant temperature and illumination. Turner and Boyle (1974) observed growth lines in shells of teredinid larvae and suggested that counts of these lines in known-age larvae would give an indication of their periodicity.

Daily growth lines in fish otoliths have been used to estimate age since the early 1970's (Campana and Neilson, 1985; Jones, 1986). Recently, the approach was extended to the statoliths of squid (Hurley et al., 1985). For growth lines to be useful in ageing, they must be deposited at a constant rate (e.g. daily). The periodicity of line deposition in otoliths of fish larvae varies among species and can be affected by environmental conditions (Campana and Neilson, 1985). Therefore, it is necessary to determine the effects of such factors as photoperiod, feeding regime and temperature on the rate of growth-line deposition.
In this paper, the relationship between number of growth lines and age of sea scallop larvae is documented. With the use of both light and scanning electron microscopy, growth lines on the shells of laboratory-reared larvae are shown to be deposited with near daily periodicity under different photoperiods.

\section{Materials and Methods}

The terminology of Chanley and Andrews (1971) was used in this paper with reference to the early stages of bivalve larvae. The first shelled stage (Prodissoconch I) consists entirely of shell deposited by the shell gland. The next stage (Prodissoconch II) consists of shell which is laid down by the mantle and contains the growth lines. Shell length is measured along the anterior-posterior axis which is parallel to the hinge. Shell height is measured along the dorsal-ventral axis which is perpendicular to the hinge.

The sea scallop larvae for this study were reared in the laboratory. Adult sea scallops were obtained from a near-shore bed off Yarmouth, Nova Scotia, and were held in off-bottom nets for 1-3 months prior to maturation for spawning. In early September 1985, the scallops were transferred to the laboratory and five individuals of each sex were held in separate containers. They were induced to spawn by raising the water temperature $3^{\circ}$ to $4^{\circ} \mathrm{C}$ above the ambient temperature of $13^{\circ} \mathrm{C}$ (Loosanoff and Davis, 1963) and by injecting $0.5 \mathrm{ml}$ of seratonin (2 millimolar) into the adductor muscle (Gibbons and Castagna, 1984). The addition of $20-30 \mathrm{ml}$ of sperm suspension from the five males was further stimulus for female spawning. The whole process was terminated within $3 \mathrm{hr}$. 
The eggs were maintained in 20-I plastic containers at a density of approximately 30 eggs per $\mathrm{ml}$ of seawater. The water was aerated and the temperature $\left(14^{\circ} \pm 1^{\circ} \mathrm{C}\right)$ was maintained by placing the containers in a thermostatically-controlled water bath. After 4 days when more than $95 \%$ of the surviving larvae had reached the Prodissoconch I stage, the water was changed and samples were taken to estimate density. The larvae were then transferred to six containers, in each of which the larval concentration was adjusted to approximately 2.5 larvae per $\mathrm{ml}$, and they were fed for the first time. Thereafter, the larvae were fed every second day within an hour after changing the water. Algae were administered such that the final concentration in each container was 13,050 cells per $\mathrm{ml}$ of /sochrysis galbana, 6,320 cells per $\mathrm{ml}$ of Chaetoceros gracilis, and 30,630 cells per $\mathrm{ml}$ of $C$. calcitrans. Changing the water may have stressed the larvae because they were trapped on fine-mesh screens during the filtering process and exposed to air for short periods (up to $15 \mathrm{sec}$ ).

The effect of photoperiod on the number of growth lines in the shells was tested by exposing three containers to alternating 12-hr periods of light and darkness (LD 12:12) and the other three containers to constant light conditions. The lighting source for both groups of larvae was 40-w fluorescent bulbs, but the lighting intensity, although not measured, was evidently greater for the larvae which were held under constant light.

Samples of larvae for growth-line counts were obtained from one randomly-selected container in each light regime on day 18 and day 28 and from each of the replicate containers on day 10 and day 24 . The larvae were preserved in $80 \%$ ethanol. The relationship between growth-line count and age was tested further by putting a chemical "time mark" on the shells. Alizarin red $(20 \mathrm{mg}$ ) was added to an additional $20-/$ container of larvae on day 22, and the water was changed $24 \mathrm{hr}$ later to remove the effect of the dye. This container was maintained under constant light conditions until day 30 when the larvae were preserved.

To prepare the shells for growth-line counts, the larvae were transferred from the ethanol preservative to a $0.3 \%$ solution of sodium hypochlorite $(5 \%$ commercial bleach). After soaking for approximately $20 \mathrm{~min}$, the shell valves began to gape. Under a stereomicroscope, the valves were teased apart with a sharp probe. Right valves were chosen for growth-line counts to ensure that both valves from the same larva were not examined and because the right valve is slightly less concave than the left (Culliney, 1974), making it a better choice for fixed-focus growth-line counts. A random sample of valves was pipetted onto a glass slide for examination under a compound photomicroscope at a magnification of 320 . Each valve was positioned with the inner side facing upward, and a cover slip was then placed on the preparation. At least 9 valves from each of the rearing containers were prepared in this way.

Growth-line counts for comparison with the actual ages (days) were made from light micrographs. A consistent focal plane for the light micrographs was achieved by maximizing the anterior-posterior distance over which lines of approximately equal contrast were in focus. This is illustrated for three focal planes in Fig. $1(A, B, C)$, of which $B$ was used for the counts. If this focal plane could not be achieved (due to cracks, unsuitable orientation, or growth lines obscured by detritus), the valve was not micrographed. Kodak Panatomic $X$ film (ASA 32) and high contrast paper were used in making the micrographs. Although some subjectivity was involved in counting growth lines, counts by two persons were in agreement for most of the specimens (>95\%). When agreement on growth-line counts could not be reached, the micrograph was rejected.

Due to the three-dimensional nature of the larval shell, a Bausch and Lomb scanning electron microscope (SEM) was used to corroborate what was seen with light microscopy. This ensured that the limitation to one focal plane in the light micrographs did not alter the apparent number of growth lines. For examination under the electron microscope, the valves were initially prepared as before for light microscopy, rinsed in distilled water and pipetted onto a nucleopore filter with pore size of 5 or $12 \mu \mathrm{m}$. The filter with valves was air-dried for at least $12 \mathrm{hr}$, placed on a SEM stub and gold-plated in a vacuum.

When growth lines on the shells were being counted, estimation of larval ages was not difficult because the sampling days and approximate sizes of larvae on these days were known. To test for bias in counting, the counters examined a sample of larvae which had been reared by Couturier (MS 1986). Growth lines on these shells were counted with no prior knowledge of larval ages.

\section{Results}

\section{Larval growth}

The growth of larval sea scallops under the two different light regimes was similar up to day 15 (Fig. 2), but, from day 18 onwards, the mean lengths of larvae under constant light conditions were significantly less $(P<0.01)$ than those reared under the LD 12:12 regime. The lower growth rate may have been related to a bluegreen algal bloom (species not identified) which was observed in the containers under constant light. 

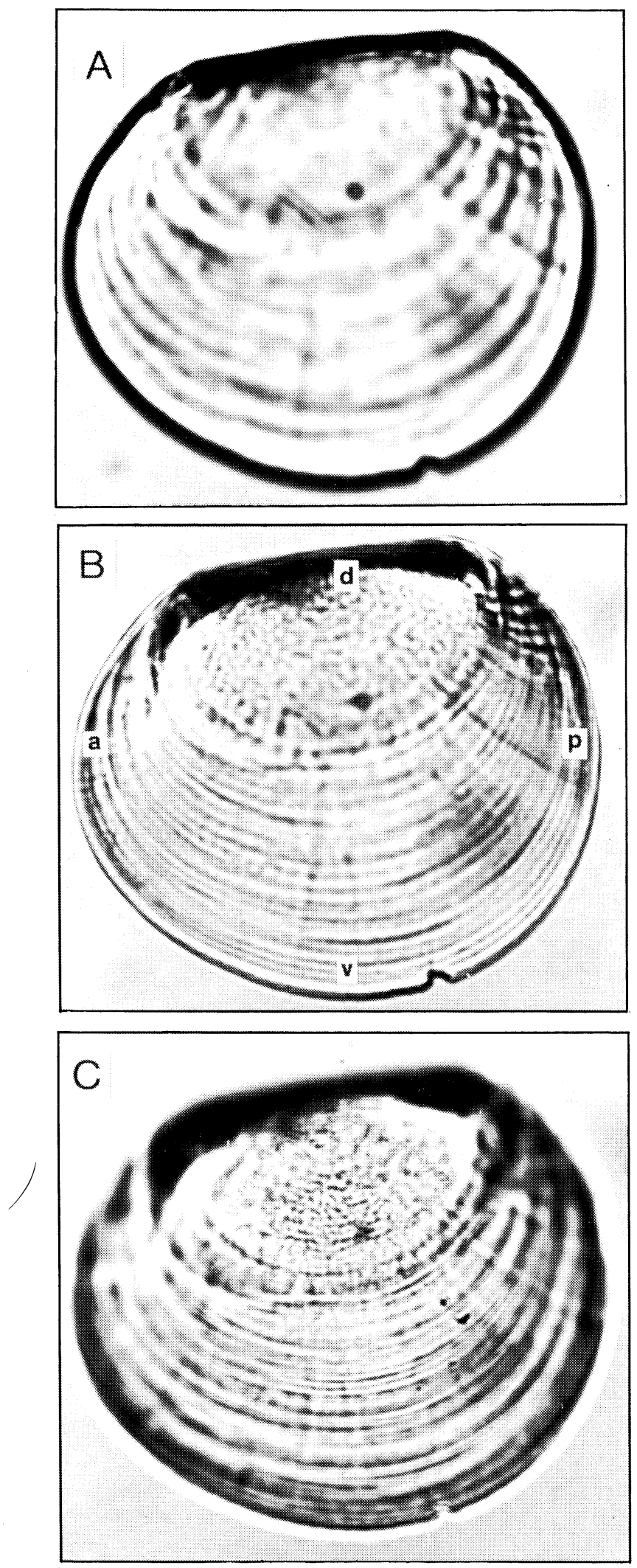

Fig. 1. Three different focal planes of the valve of a 24-day-old sea scallop larva. B was the plane used for counting. $(a=$ anterior $d=$ dorsal, $p=$ posterior,$v=$ ventral.)

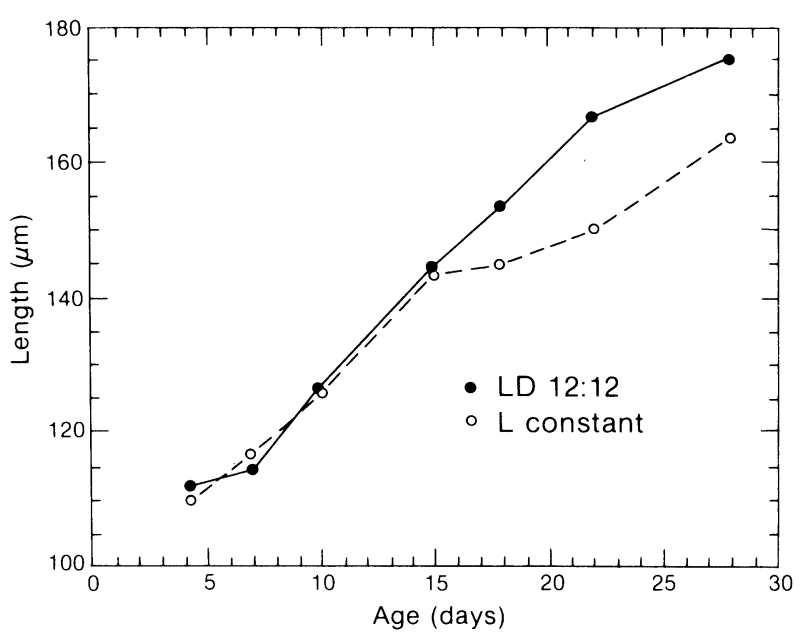

Fig. 2. Growth of sea scallops larvae reared under two daily light regimes: $24 \mathrm{hr}$ of constant light ( $\mathrm{L}$ constant) and alternating $12 \mathrm{hr}$ of light and $12 \mathrm{hr}$ of darkness (LD 12:12). Each point represents the mean of 25 length measurements from the same container.)

\section{Visual appearance of growth lines}

The first growth line was deposited on the third or fourth day after fertilization. The line was apparent on shells of 4-day-old larvae under both SEM and light microscopy (Fig. 3). For this reason, all growth-line counts were transformed to estimates of age (days) by the addition of 3 days. Prodissoconch I corresponds to the central region of 4-day-old shells with shallow punctate marks (Fig. 3A). Prodissoconch II is distal to the central region and contains the growth lines. The lines were observed to be ridges under the electron microscope, and the prominence of these ridges enabled the distinguishing of "major" and "minor" growth lines (Fig. 4). The distance between adjacent major lines ranged from 1.8 to $6.5 \mu \mathrm{m}$, whereas adjacent minor lines were less than $1 \mu \mathrm{m}$ apart.

For each specimen, the number of major growth lines from SEM examination (Fig. 4) corresponded closely to the number of lines apparent on the light micrographs (Fig. 5), but there were too few SEM micrographs to allow a statistical comparision. However, in five SEM micrographs of the shells of 24-day old larvae, the mean count of major growth lines was 20.4 , which is very similar to the mean growth-line counts from light micrographs of the shells of 24-dayold larvae (see Table 1).

\section{Actual and estimated ages}

A non-parametric test (Kruskal-Wallis), based on ranked ages, was used to test for the effects of sampling different containers and different light regimes on growth-line counts. A parametric procedure (e.g. analysis of variance) was not used because assumptions of normal distribution and homoscedasticity were not met by the growth-line data. Estimated ages of larvae 

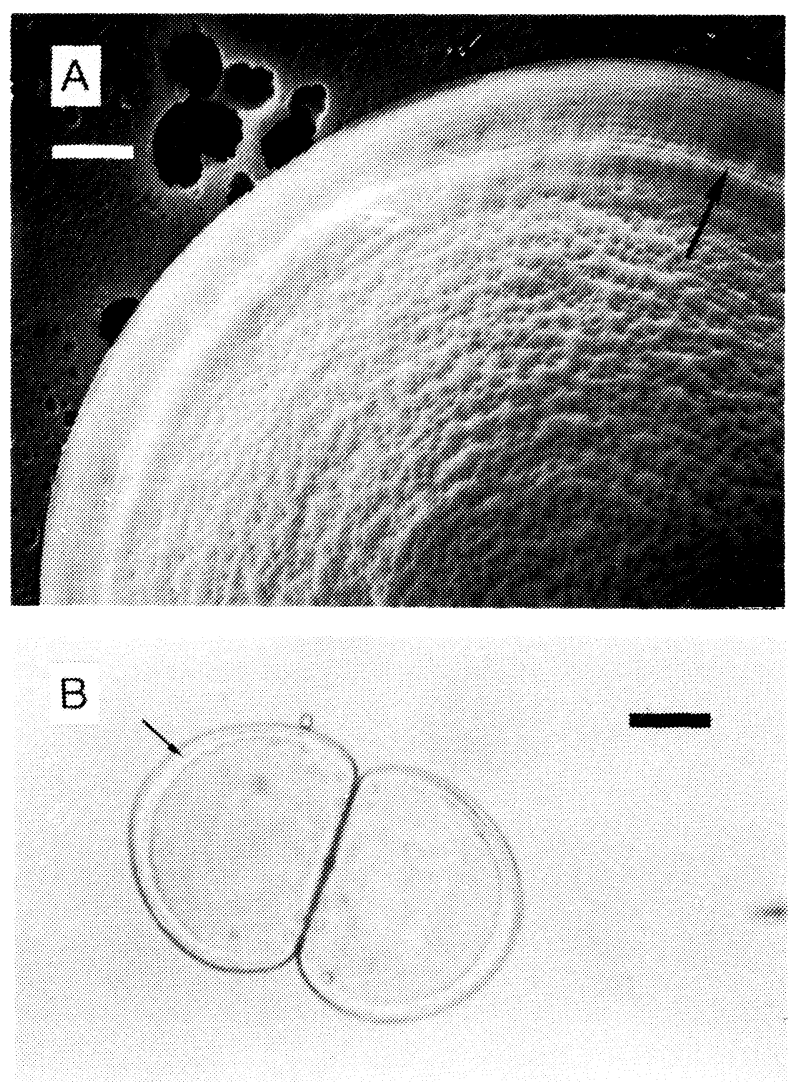

Fig. 3. Valves from 4-day-old sea scallop larva showing the first growth line (arrow): A, scanning electron micrograph of outer portion of valve ( $\mathrm{bar}=8.33 \mu \mathrm{m}$ ); $\mathbf{B}$, light micrograph of interior view of valves still attached at hinge $($ bar $=33 \mu \mathrm{m})$.

(growth-line counts plus 3) from the three containers under each light regime and on each sampling date were not significantly different (Table 1). Consequently, the data for samples from the three containers were combined. Photoperiod had no significant effect on estimated ages of larvae which were sampled on days $10,18,24$ and 28 (Table 2). Data for both photoperiods were pooled to rank correlate the estimate ages with actual ages. The resultant Spearman correlation coefficient of 0.93 indicated very good agreement between the estimated and actual ages.

Estimated ages (without prior knowledge of actual ages) of larvae which were reared by Couturier (MS 1986) were, on the average, quite similar to the actual ages (Table 3). The Spearman rank correlation of estimated ages with actual ages gave a high coefficient of 0.96 . Thus, the estimated ages of larvae in the present study (Tables 1 and 2) are unlikely to have been biased by prior knowledge of the sampling dates.

\section{Alizarin red as a shell marker}

Alizarin red affected both the behavior and shell structure of the larvae, although the dye was not visible in the shell. During immersion in the alizarin red solu-
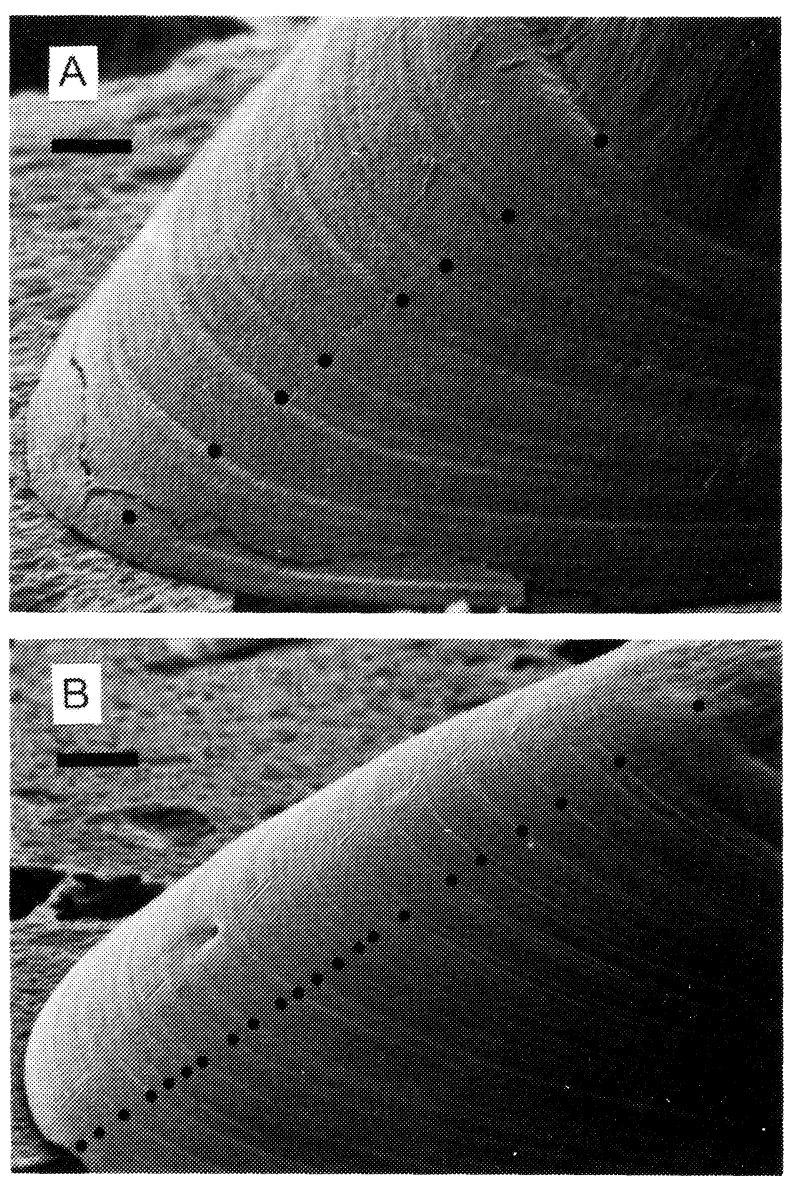

Fig. 4. Scanning electron micrographs of interior view of sea scallop valves: A, 10-day-old larva with 8 growth lines cultured under the LD 12:12 regime (bar $=3.88 \mu \mathrm{m}$ ); B, 24-day-old larva with 22 growth lines cultured under the $L$ constant regime.

tion, the larvae swam much less than previously and tended to remain close to the bottom of the container. The direction of shell growth changed during the 24-hr immersion period, and detection of a growth line was difficult (Fig. 6). During the 7 days after removal of the alizarin red by changing the water, 8 narrowly-spaced growth lines were formed.

\section{Discussion}

This study is the first to relate the number of growth lines in the shells of sea scallop larvae to the actualage in days. Estimated ages from counts of growth lines on light micrographs of shells of laboratory-reared larvae were significantly correlated with actual ages. The growth lines were formed on a "near daily" basis, beginning on day 3 or day 4 after fertilization.

The three-dimensional nature of the shells of sea scallop larvae presents a problem when light microscopy is used to view and photograph the growth lines This may account for the difference between estimated and actual ages for some of the specimens (Tables 1 


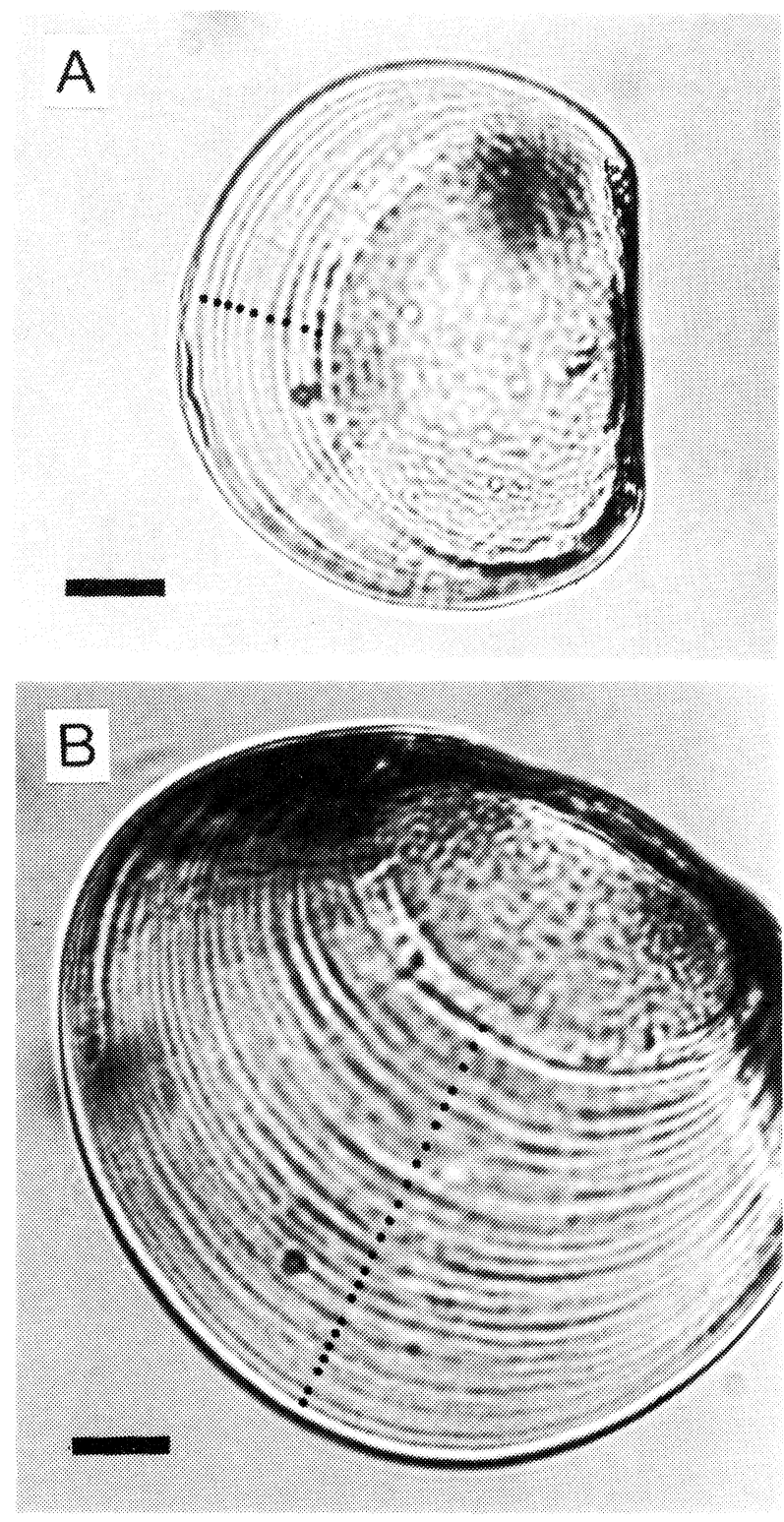

Fig. 5. Light micrographs of interior view of sea scallop valves: $\mathbf{A}$ 10-day-old larva with 9 growth lines cultured under the $L$ constant regime $(\mathrm{bar}=22 \mu \mathrm{m})$; B, 24-day-old larva with 23 growth lines cultured under the LD 12:12 regime (bar $=$ $19 \mu \mathrm{m})$.

and 2). The fixed focal-plane appeared to be a good approach, because it can be consistently achieved, it results in reasonably good estimates of actual ages, and the light micrograph provides a record of each specimen. There appeared to be good correspondence between the number of "major" lines on SEM micrographs and the growth-line count on light microg raphs of larvae of the same age, but SEM microscopy is considered to be too expensive and time-consuming for routine use. The "minor" lines, which were apparent on the SEM micrographs, were less visible (out of focus) on the light micrographs.
TABLE 1. Estimated ages of sea scallop larvae, reared in three containers (lots) under two light regimes, on day 10 and day 24 after fertilization. (Probabilities (P) from Kruskal-Wallis Test based on ranked ages.)

\begin{tabular}{|c|c|c|c|c|c|c|}
\hline \multirow{2}{*}{$\begin{array}{c}\text { Actual } \\
\text { age } \\
\text { (days) }\end{array}$} & \multirow{2}{*}{$\begin{array}{l}\text { Light } \\
\text { regime }\end{array}$} & \multirow{2}{*}{$\begin{array}{l}\text { Lot } \\
\text { No. }\end{array}$} & \multirow{2}{*}{$\begin{array}{l}\text { No. of } \\
\text { larvae }\end{array}$} & \multicolumn{2}{|c|}{$\begin{array}{c}\text { Estimated age (days) } \\
\text { (growth lines }+3 \text { ) }\end{array}$} & \multirow[b]{2}{*}{$P$} \\
\hline & & & & Range & Mean & \\
\hline \multirow[t]{6}{*}{10} & LD $12: 12$ & 1 & 10 & $9-12$ & 10.8 & \\
\hline & & 2 & 10 & $9-12$ & 11.0 & 0.29 \\
\hline & & 3 & 10 & $10-13$ & 11.7 & \\
\hline & L constant & 1 & 10 & $9-13$ & 10.7 & \\
\hline & & 2 & 10 & $9-13$ & 10.7 & 0.97 \\
\hline & & 3 & 10 & $8-12$ & 10.3 & \\
\hline \multirow[t]{6}{*}{24} & LD $12: 12$ & 1 & 9 & $24-26$ & 24.7 & \\
\hline & & 2 & 9 & $22-27$ & 24.7 & 0.52 \\
\hline & & 3 & 10 & $23-29$ & 25.5 & \\
\hline & L constant & 1 & 10 & $23-28$ & 25.4 & \\
\hline & & 2 & 10 & $23-27$ & 25.5 & 0.14 \\
\hline & & 3 & 10 & $22-26$ & 24.3 & \\
\hline
\end{tabular}

TABLE 2. Estimated ages of sea scallop larvae, reared under two light regimes, on days $10,18,24$ and 28 after fertilization. (Probabilities $(P)$ from Kruskal-Wallis Test based on ranked ages.)

\begin{tabular}{|c|c|c|c|c|c|}
\hline \multirow{2}{*}{$\begin{array}{l}\text { Actual } \\
\text { age } \\
\text { (days) }\end{array}$} & \multirow{2}{*}{$\begin{array}{l}\text { Light } \\
\text { regime }\end{array}$} & \multirow{2}{*}{$\begin{array}{l}\text { No. of } \\
\text { larvae }\end{array}$} & \multicolumn{2}{|c|}{$\begin{array}{l}\text { Estimated age (days) } \\
\text { (growth lines }+3)\end{array}$} & \multirow[b]{2}{*}{$\mathrm{P}$} \\
\hline & & & Range & Mean & \\
\hline \multirow[t]{2}{*}{10} & LD $12: 12$ & 30 & $9-13$ & 11.2 & \multirow{2}{*}{0.09} \\
\hline & $\mathrm{L}$ constant & 30 & $8-13$ & 10.6 & \\
\hline \multirow[t]{2}{*}{18} & LD $12: 12$ & 10 & $17-21$ & 18.9 & \multirow{2}{*}{0.78} \\
\hline & L constant & 10 & $16-23$ & 18.8 & \\
\hline \multirow[t]{2}{*}{24} & LD $12: 12$ & 28 & $22-29$ & 25.0 & \multirow{2}{*}{0.77} \\
\hline & L constant & 30 & $22-38$ & 25.1 & \\
\hline \multirow[t]{2}{*}{28} & LD $12: 12$ & 10 & $25-30$ & 28.0 & \multirow{2}{*}{0.81} \\
\hline & L constant & 10 & $26-30$ & 27.9 & \\
\hline
\end{tabular}

TABLE 3. Estimated ages of sea scallop larvae in a sample of those reared by Couturier (MS 1986). (Ages were determined without prior knowledge of actual age.)

\begin{tabular}{cccc}
\hline $\begin{array}{c}\text { Actual } \\
\text { age } \\
\text { (days) }\end{array}$ & $\begin{array}{c}\text { No. of } \\
\text { larvae }\end{array}$ & \multicolumn{2}{c}{$\begin{array}{c}\text { Estimated age (days) } \\
\text { (growth lines + 3) }\end{array}$} \\
\cline { 3 - 4 } & Range & Mean \\
\hline 13 & 4 & $13-15$ & 13.8 \\
15 & 7 & $13-19$ & 15.6 \\
18 & 10 & $15-22$ & 18.0 \\
22 & 10 & $21-23$ & 21.9 \\
28 & 10 & $23-33$ & 28.1 \\
32 & 10 & $29-37$ & 32.1 \\
\hline
\end{tabular}

Millar (1968) examined the shells of European oyster (Ostrea edulis) larvae and found major rings (growth lines), which seemed to correspond in number to the number of days after the larvae were released, and several minor rings between adjacent major rings. Growth lines on the shells of larval sea scallops appear to fit this pattern. Growth lines with different degrees of prominence were apparent on the shells of common 

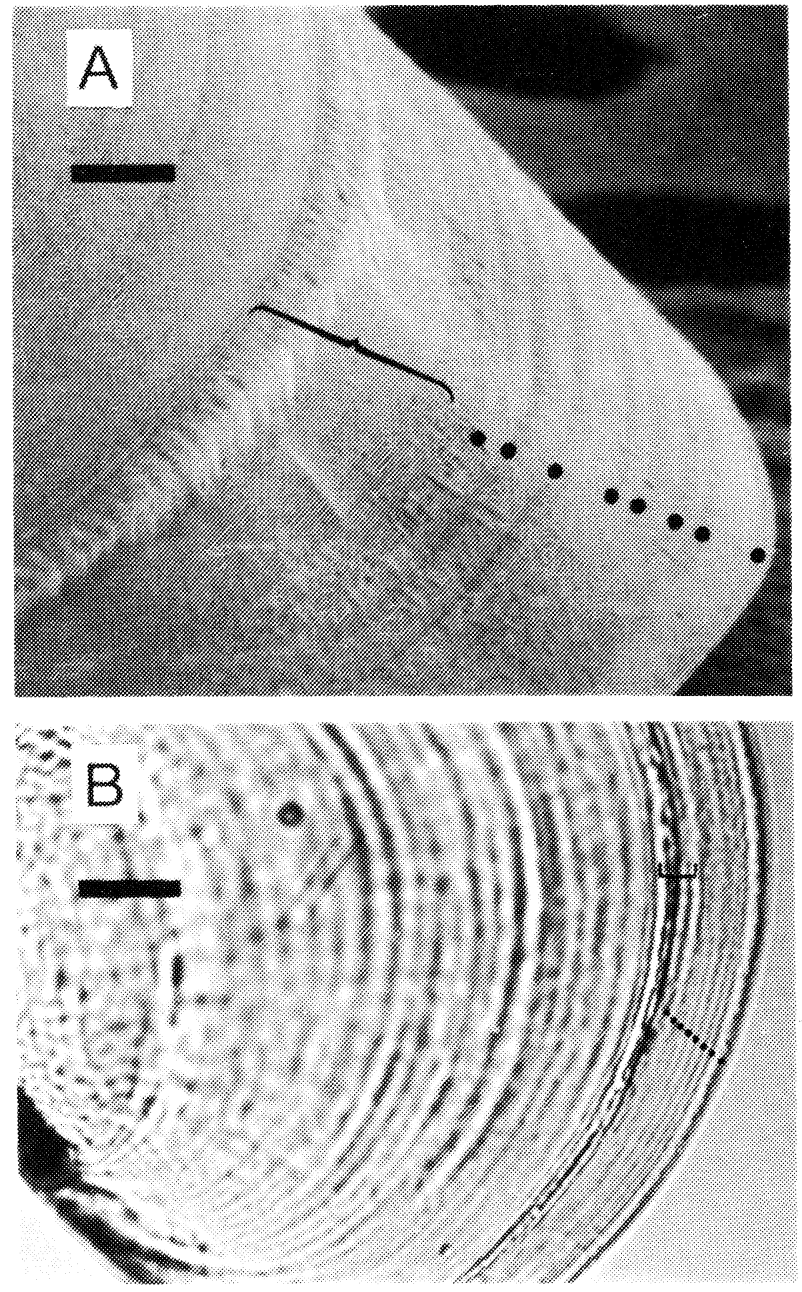

Fig. 6. Valves of 30-day-old sea scallop larvae marked with alizarin red when 22 days old: $\mathbf{A}$, scanning electron micrograph (bar = $3.87 \mu \mathrm{m}$ ); B, light micrograph (bar $=18 \mu \mathrm{m}$ ). (Brackets point to mark produced by alizarin red, and both micrographs show 8 growth lines after the mark.)

oyster (Crassostrea virginica) larvae but were not interpreted chronologically (Carriker and Palmer, 1979).

During the present experiment, the seawater was changed every second day, and the sea scallop larvae were probably stressed during the short periods of exposure to air on the screens. However, there was no evidence of this stress in the pattern of growth lines on the shells. This implies that the stress of routine maintenance of the larvae did not influence growth-line formation.

Exposure of larvae to alizarin red dye in the seawater for $24 \mathrm{hr}$ was sufficient to deform the shell (Fig. 6). Growth of the shell (i.e. distance between adjacent growth lines) during the immersion period appeared to be more similar to growth in the preimmerson period than in the postimmersion period. Nevertheless, eight lines were formed after removal of the seawater containing the red dye. This is consistent with the expectation that 7 or 8 lines would be formed, depending on the time of day when growth-line formation occurs. This demonstrates that daily growth-line deposition can resume after short-term stress. However, the mortality which may be associated with exposure to alizarin red was not measured. Dey and Bolton (1978) used tetracycline as a bivalve shell marker and noted an increase in shell growth rate after marking. An innocuous shell marker would be useful for further work of this type.

The formation of growth lines in sea scallop shells on a daily basis, even when the larvae were reared under constant light, indicates that photoperiod does not affect the rate of shell deposition. This implies endogenous control of growth-line formation, which has been postulated for some species of adult bivalves (Clark, 1975; Thompson, 1975) and for oyster larvae (Millar, 1968). Indirect support for endogenous control is the presence of growth lines in bivalve larvae from constant environments such as deep-sea vents (Lutzet al., 1980). To determine if there is endogenous control of growth-line deposition in larval sea scallops will require investigation of the effects of such factors as temperature, starvation and feeding frequency. ${ }^{\star}$

\section{Acknowledgements}

We acknowledge the dedicated effort of R. Hartt in rearing the scallop larvae and preparing the shells for ageing. The cooperation of $\mathrm{N}$. Balch, manager of the Aquatron Laboratory at Dalhousie University, Halifax, Nova Scotia, is greatly appreciated. Valuable assistance with the scanning electron microscope was provided by $C$. Mason and statistical advice was given generously by P. Fanning and S. Smith, Bedford Institute of Oceanography, Dartmouth, Nova Scotia. The work was funded by the Canadian Department of Supply and Services and the Department of Fisheries and Oceans under a contract awarded to Hurley Fisheries Consulting Ltd.

\section{References}

CAMPANA, S. E., and J. D. NEILSON. 1985. Microstructure of fish otoliths. Can. J. Fish. Aquat. Sci., 42: 1014-1032.

CARRIKER, M. R., and R. E. PALMER. 1979. UItrastructural morphogenesis of prodissoconch and early dissoconch values of the oyster Crassostrea virginica. Proc. Natl. Shellfish. Assoc., 69: 103-128.

CHANLEY, P., and J. D. ANDREWS. 1971. Aids for identification of bivalve larvae of Virginia. Malacologia, 11: 45-119.

\footnotetext{
* Just before publication of this paper, the second author (M. J. Tremblay) was completing a study which indicated that growth-line number can be influenced by starvation and temperature. Larvae being reared at $11^{\circ} \mathrm{C}$ and starved for $2-6$ days had $27-30 \%$ fewer growth lines than those which were reared at $14^{\circ} \mathrm{C}$ and fed regularly (every 2 days)
} 
CLARK, G. R. 1968. Mollusk shell: daily growth lines. Science, 161: $800-802$.

1974. Growth lines in invertebrate skeletons. Annu. Rev. Earth Planet. Sci., 2: 77-99.

1975. Periodic growth and biological rhythms in experimentally grown bivalves. In: Growth rhythms and the history of the earth's rotation (p. 103-117), G. D. Rosenberg and K. Runcorn (ed.), John Wiley and Sons, London, Engl., $559 \mathrm{p}$.

COUTURIER, C. Y. MS 1986. Aspects of reproduction and larval production in Placopecten magellanicus held in a semi-natural environment. M.Sc. Thesis, Dalhousie Univ., Halifax, N. S., 108 p.

CULLINEY, J. L. 1974. Larval development of the giant scallop Placopecten magellanicus (Gmelin). Biol. Bull., 147: 321 332.

DEY, N. D., and E. T. BOLTON. 1978. Tetracycline as a bivalve shell marker. Proc. Natl. Shellfish Assoc., 68: 77.

GIBBONS, M. C., and M. CASTAGNA. 1984. Seratonin as an inducer of spawning in six bivalve species. Aquaculture, 40: $189-191$.

HURLEY, G. V., P. H. ODENSE, R. K. O'DOR, and E. G. DAWE. 1985. Strontium labelling for verifying daily growth increments in the statolith of the short-finned squid (IIlex illecebrosus). Can. J. Fish. Aquat. Sci., 42: 380-383.
JONES, C. 1986. Determining age of larval fish with the growth increment technique. Fish. Bull. U.S., 84: 91-103.

JONES, D. S. 1983. Sclerochronology: reading the record of the molluscan shell. Amer. Sci., 71: 384-391.

LOOSANOFF, V. L., and H. C. DAVIS. 1963. Rearing of bivalve molluscs. Adv. Mar. Biol., 25: 233-238.

LUTZ, R. A., D. JABLONSKI, D. C. RHOADS, and R. D. TURNER. 1980. Larval dispersal of a deep-sea hydrothermal vent bivalve from the Galapagos Rift. Mar. Biol., 57: 127-133.

MILLAR, R. H. 1968. Growth lines in the larvae and adults of bivalve molluscs. Nature, 217: 689.

RHOADS, D. C., and R. A. LUTZ. 1980. Skeletal growth of aquatic organisms. Plenum Press, New York, N. Y., 750 p.

THOMPSON, I. 1975. Biological clocks and shell growth in bivalves. In: Growth rhythms and the history of the earth's rotation (p. 149-161), G. D. Rosenberg and K. Runcorn (ed.), John Wiley and Sons, London, Engl., $559 \mathrm{p}$.

THOMPSON, I., D. S. JONES, and D. DREIBELBIS. 1980. Annual internal growth banding and life history of the ocean quahog Artica is/andica (Mollusca, Bivalvia). Mar. Biol., 57: 25-34.

TURNER, R. D., and P. J. BOYLE. 1974. Studies of bivalve larvae using the scanning electron microscope and critical point drying. Bull. Amer. Malacol. Union, 12: 59-65. 
